\title{
Acute cadmium poisoning in a foreman plater welder
}

\author{
D H Yates, K P Goldman
}

Poisoning from exposure to fresh cadmium fumes at work has long been described but cases may remain undiagnosed. The diagnosis of acute cadmium poisoning should be considered in any workman who has been occupied in high temperature welding in confined spaces. Surfaces electroplated with cadmium may go unrecognised and present a significant hazard. Freshly formed cadmium oxide fumes may cause pulmonary oedema and hepatic and renal failure, leading to severe illness and even to death. This hazard is entirely preventable with proper fume extraction and awareness on the part of worker and occupational physician alike.

\section{Case report}

A 49 year old ex-smoker had worked as a plater welder at a ship repairers for 20 years. He was often engaged in silver brazing on copper pipes and would occasionally use an alloy containing $20 \%$ cadmium.

Department of Health and Social Security, London SE1 8EU

D H Yates

West Hill Hospital, Dartford, Kent

K P Goldman
In February 1985 he spent two weeks brazing ships' propellors with an oxyacetylene torch using the cadmium alloy in a confined area with poor ventilation. He was the only worker. Many fumes were produced. He was wearing simple respiratory protection.

After about ten days work he started to notice malaise and some breathlessness. He was, however, keen to finish the job and thus continued work. He developed fever, arthralgia, and had a small haemoptysis in the evening of completing the job.

Examination at the local chest clinic in March 1985 showed widespread inspiratory crackles over both lower lobes. Chest radiograph (fig 1) showed bilateral lower zone mottled shadowing. Simple lung function showed a restrictive picture (table). Full blood count was normal with an ESR of 30 and autoantibodies were negative. Results of urine testing were normal. Fibrosing alveolitis was diagnosed and he started taking prednisolone $40 \mathrm{mg}$ once a day as an outpatient. He remained off work.

Three weeks later there had been considerable clinical, radiological, and physiological improvement (fig 2). The basal crackles had diminished. He continued taking steroids in a decreased dosage. At a

Figure 1 Chest radiograph appearances on presentation (March 1985).

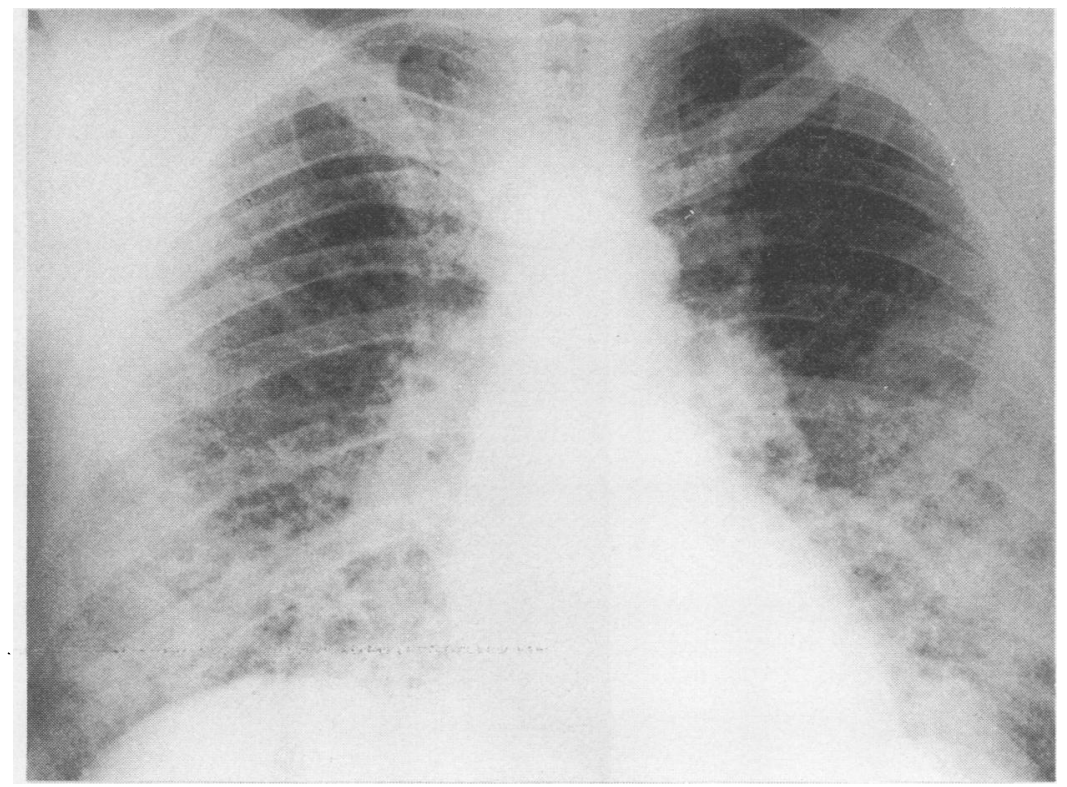


Table Vitalograph lung function

\begin{tabular}{|c|c|c|c|c|c|c|c|c|}
\hline & $\begin{array}{l}\text { Predicted } \\
\text { values }\end{array}$ & $\begin{array}{l}\text { 21 March } \\
1985\end{array}$ & $\begin{array}{l}11 \text { April } \\
1985\end{array}$ & $\begin{array}{l}6 \text { June } \\
1985\end{array}$ & $\begin{array}{l}10 \text { October } \\
1985\end{array}$ & $\begin{array}{l}1 \text { May } \\
1986\end{array}$ & $\begin{array}{l}7 \text { August } \\
1986\end{array}$ & $\begin{array}{l}16 \text { June } \\
1987\end{array}$ \\
\hline $\begin{array}{l}\text { FEV } \\
\text { FVC } \\
\text { FEV }_{1} / \text { FVC }^{\prime} \text { 。 }\end{array}$ & $\begin{array}{c}3 \cdot 2-4 \cdot 4 \\
4 \cdot 2-5 \cdot 8 \\
68-79\end{array}$ & $\begin{array}{l}2 \cdot 2 \\
2 \cdot 8 \\
85\end{array}$ & $\begin{array}{r}3 \cdot 4 \\
4 \cdot 0 \\
86 \cdot 3\end{array}$ & $\begin{array}{r}3.4 \\
4 \cdot 4 \\
77 \cdot 2\end{array}$ & $\begin{array}{r}3 \cdot 4 \\
4 \cdot 4 \\
77 \cdot 2\end{array}$ & $\begin{array}{r}3.5 \\
4.8 \\
72 \cdot 9\end{array}$ & $\begin{array}{r}3.5 \\
4.9 \\
71 \cdot 4\end{array}$ & $\begin{array}{l}3 \cdot 8 \\
5 \cdot 5 \\
69\end{array}$ \\
\hline
\end{tabular}

Height $187 \mathrm{~m}$; weight $114.8 \mathrm{~kg}$.

two month follow up the improvement had been maintained and he commented that his breathing was almost back to normal (fig 3). He returned to work. By May 1986 he was not taking steroids and felt fit.

He eventually applied for industrial disablement benefit when the diagnosis of acute cadmium poisoning was established. There were no abnormal physical findings. Chest radiographs had returned to normal. Full lung function testing was within normal limits. Results of full blood count, urea and electrolytes, liver function tests, and plasma proteins were all normal. Serum creatinine was $9 \mu \mathrm{mol} / 1$, creatinine clearance $152 \mathrm{ml} / \mathrm{min}$, blood cadmium 25 $\mathrm{nmol} / \mathrm{l}$ (normal), urinary cadmium $19 \mathrm{nmol} / 1$ or 1.3 $\mathrm{nmol} / \mathrm{mmol}$ creatinine (normal), urine retinol binding protein $11 \mu \mathrm{g} / \mathrm{mmol}$ creatinine (normal). It was concluded that there were no detectable residual respiratory or renal effects at the time of examination. Unfortunately no serum had been retained from the time of the illness to check the blood cadmium concentration.

\section{Discussion}

Acute cadmium pneumonitis is an unusual but potentially lethal hazard of oxyacetylene welding. Cadmium is highly resistant to corrosion and is therefore used in electroplating and in the rustproof- ing of iron and steel articles including nuts, bolts, $\vec{\circ}$ washers, tools, and bearings. It is used to protect $\rightarrow$ articles in contact with sea water such as ships' $\vec{\omega}$ propellors. Silver brazing is particularly hazardous because temperatures are high and a silver alloy filler $\frac{\mathbb{\Phi}}{3}$ commonly containing cadmium is used, often in enclosed and poorly ventilated areas. ${ }^{1}$ Welders are. familiar with the less dangerous metal fume fever produced by inhaling copper, zinc, and other metallic fumes and may therefore dismiss initial symptoms. ${ }^{2}$ 응

Cadmium has many other uses including preparing pigments for paints, in nickel cadmium storage batteries, as an antifriction agent in metal bearings,, and in copper alloys for cables and trolley wires. ${ }^{3} \mathrm{It}^{\Phi}$ may thus occur where its presence is unsuspected and $\vec{\emptyset}$ therefore precautions are not taken.

Heating of cadmium containing metals to a temperature of about $321^{\circ} \mathrm{C}\left(610^{\circ} \mathrm{F}\right)$ will produce a golden yellow smoke consisting of minute particles of cadmium oxide; this looks different from zinc containing smoke which is smokey grey. ${ }^{4}$ The danger is greater than with zinc because concentrations high $\stackrel{\vec{\rho}}{\vec{\rho}}$ enough to cause severe illness or death may produce $\frac{0}{3}$ only minor warning symptoms. In addition there is the risk of an explosion as finely divided cadmium of particulate size is inflammable.

Cadmium fume is rapidly absorbed after inhala-

Figure 2 Significant clearing of chest radiograph three weeks later (April 1985).

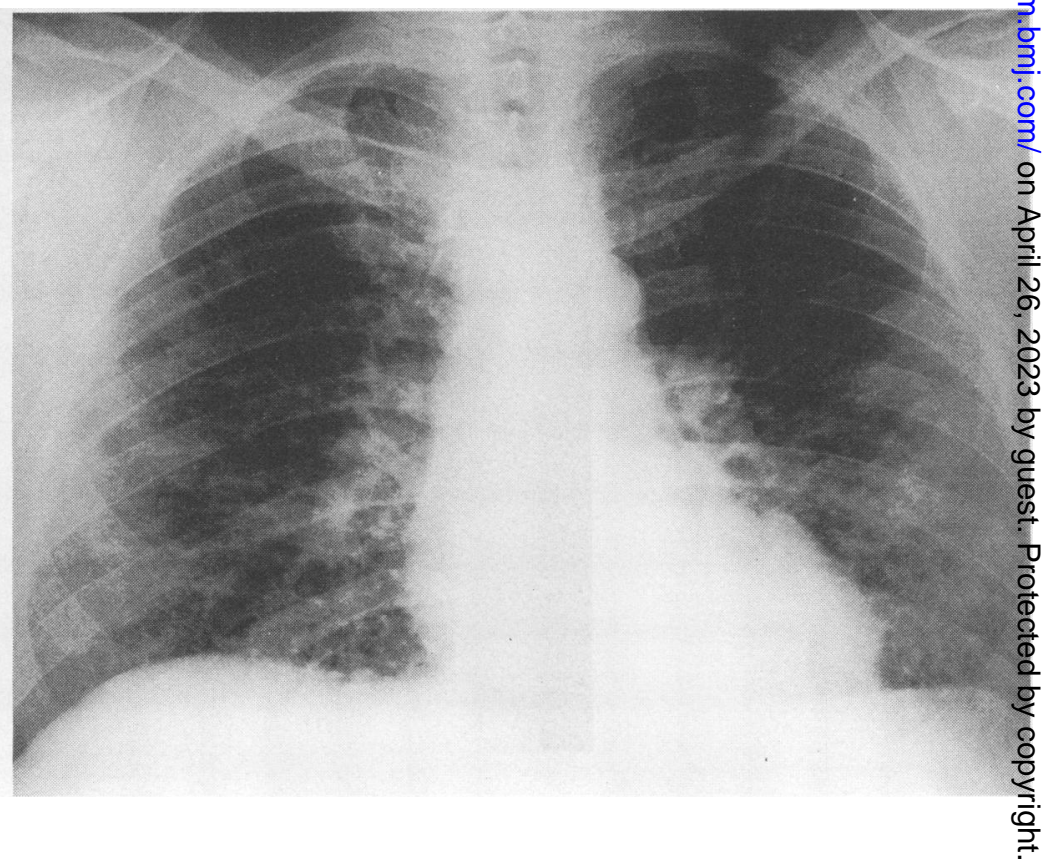


Figure 3 Normal radiograph appearance by early 1986.

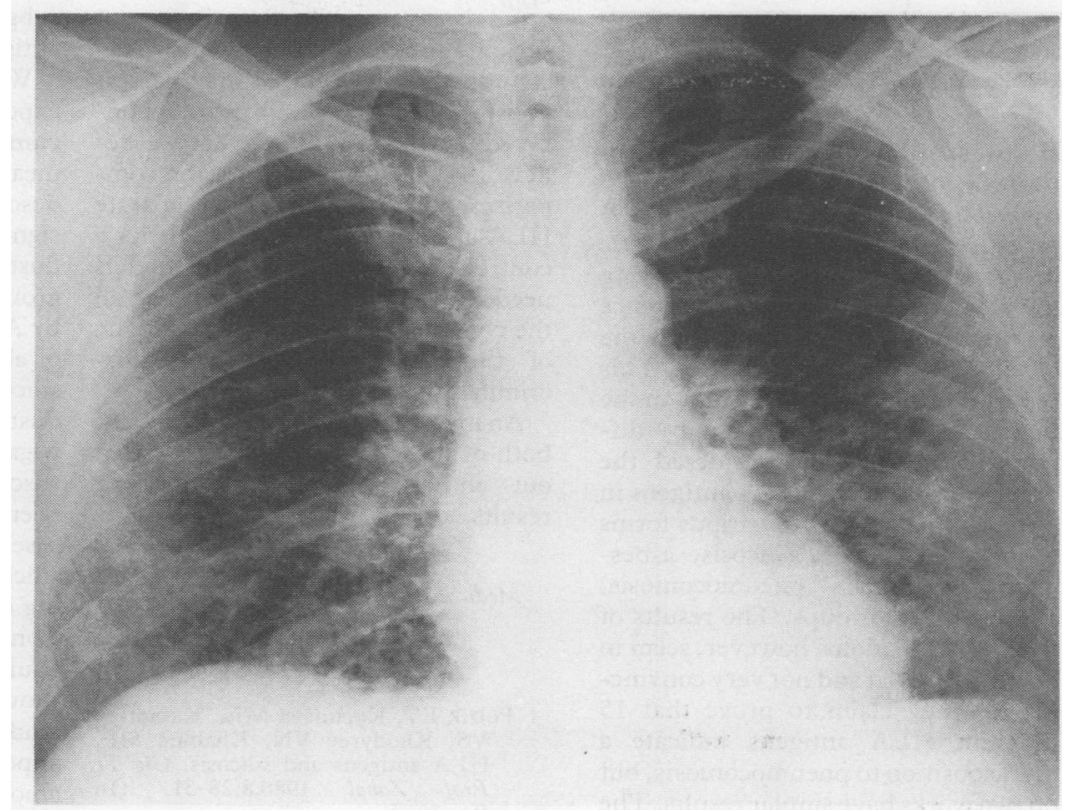

tion and immediate effects may include dryness and irritation of the throat, retrosternal chest tightness, and cough. ${ }^{5}$ Delayed effects usually appear four hours or so after exposure with onset of increasing breathlessness, nausea, headache, myalgia, retching, and occasional diarrhoea. A chemical pneumonitis is produced resulting in pronounced pulmonary oedema and the accumulation of proteinaceous fluid in the alveoli and terminal airways. Intra-alveolar haemorrhage may result in haemoptysis. In addition a severe toxic nephrosis may occur with cortical necrosis. Liver damage may also occur. Death may occur within a week of exposure. ${ }^{6}$

Physical signs are those of a pneumonitis, with increased respiratory rate and bilateral basal inspiratory crackles. Recovery in moderate cases is usually complete with no long term respiratory complications (although one case of progressive pulmonary fibrosis has been reported). ${ }^{7}$ This differs from chronic cadmium inhalation where emphysema and renal toxicity may occur. ${ }^{89}$ Corticosteroids are usually given in acute chemical pneumonitis, although there have been no controlled trials to prove their efficacy.

Our case shows the classic features of acute cadmium pneumonitis and emphasises the importance of taking a careful occupational history. Levels of cadmium oxide fume were probably generated both from the propellor and from using the cadmium containing alloy, and continued exposure resulted in eventual toxicity. Similar cases have been previously reported. ${ }^{610}$

A clinical history of fever, sweating, malaise, breathlessness, and cough occurring four to six hours after exposure at work and persisting is consistent with chemical hypersensitivity pneumonitis, and an aetiological agent should be searched for even if not immediately apparent. An alert physician may prevent further poisoning not only of the patient but also of other members of the workforce. Adequate ventilation should be ensured and respiratory protection worn with removal from exposure at onset of any relevant symptoms. Acute cadmium poisoning has been a compensable disease since $1957^{11}$ and an application for industrial disablement benefit may be made retrospectively (prescribed disease No C 18). ${ }^{12}$ Although uncommon, an awareness of the condition may be potentially life saving.

Case details published with the kind permission of Dr W R O Eggington, chief medical adviser, Department of Social Security.

1 Beton DC, Andrews GS, Davies HJ, et al. Acute cadmium poisoning: five cases with one death from renal necrosis. $\mathrm{Br} J$ Ind Med 1966;23:292-301.

2 Blejer HP, Caplan PE. Occupational health aspects of cadmium inhalation poisoning with special reference to welding and silver brazing. 2nd ed. California Bureau of Occupational Health and Environmental Epidemiology, 1971.

3 Parkes WRP. Occupational lung disorders. 2nd ed. London: Butterworths, 1982.

4 Ross P. Cadmium poisoning. Br Med J 1944;i:252-3.

5 Legge TM. Annual report of the Chief Inspector of Factories, 1924. London: HMSO, 1925:462-3. (Cmd 2437.)

6 Lucas PA, Jarriwalla AG, Jones JH, et al. Fatal cadmium fume inhalation. Lancet 1980;i:205.

7 Townshend RH. Acute cadmium pneumonitis: a 17 year follow up. Br J Ind Med 1982;39:411-2.

8 Editorial. Cadmium and the lung. Lancet 1973;ii:1134-5.

9 Davison AG, Fayers PM, Newman Taylor AJ, et al. Cadmium fume inhalation and emphysema. Lancet $1988 ; \mathrm{i}: 663-7$.

10 Patwardhan JR, Finckh ES. Fatal cadmium fume pneumonitis. Med J Aust 1975;25:962-4.

11 Industrial Injuries Advisory Council. Cadmium poisoning. London: HMSO, 1957. (Cmd 9674.)

12 Department of 'Social Security. Pneumoconiosis and other prescribed respiratory diseases. London: HMSO, 1989. (Leaflet No: NI 226.)

Accepted 11 December 1989 